\title{
Day Times Nanogram Per Milliliter Per Milligram Per Gram
}

National Cancer Institute

\section{Source}

National Cancer Institute. Day Times Nanogram Per Milliliter Per Milligram Per Gram.

NCI Thesaurus. Code C117904.

Day times nanog ram per milliliter, divided by milligram per gram. 